\title{
How Targeting Goes Astray: Explaining the Gap Between Intentions and Outcomes
}

This chapter addresses puzzles that were identified in the previous chapter. First, if partisan voters have a higher probability of being targeted for vote buying, while mass partisanship in Indonesia is comparatively weak, how feasible is it for candidates to win only by targeting partisans? Second, how can we explain the gap between politicians' insistence that they are predominantly targeting party loyalists and the reality that so much cash and goods end up in the hands of non-partisan voters? This second puzzle raises a further question about the criteria that politicians and brokers actually use when identifying the loyal voters they wish to target.

With respect to the first of these puzzles, I argue that given partisan voters are limited in number and fought over among multiple candidates from the same party, candidates first target the party constituencies they think will be likely to support them personally. However, to clinch victory, they need to seek support beyond their own traditional party bases, and they leverage personal connections in order to do so. This, in turn, has to do with the second puzzle: given they are so dependent on personal networks, candidates and brokers misrepresent personal connections as partisan leanings. They say they are targeting partisan voters, when in reality they are targeting voters who are connected to them, or to their brokers, by personal ties. By emphasising this point, I offer a contribution to the long-standing debate between advocates of core- versus swing-voter models of vote buying by integrating analysis of the core-voter strategy with an emphasis on personal networks. I argue that candidates and brokers' 
targeting strategies are misdirected; they plan to target partisan voters, but in fact they distribute most benefits to voters embedded in personal networks, who they presume to be loyal (but in fact are quite often only weakly connected to them). Put simply, candidates and brokers misidentify, or even exaggerate, the number of partisan voters because they typically blur the line between partisan and personal loyalties.

This interpretation, however, leaves a question unanswered: why should candidates get it so wrong? We know from comparative literature that brokers have an incentive to exaggerate the number of partisan, loyalist voters, ${ }^{1}$ even to deceive their candidates on this issue, so that they can engage in predation. But candidates don't have any such incentive. In addition to the mistargeting story, this chapter accordingly argues that many of the people who are connected through personal networks are in fact not even loyal to the candidate. This is largely because candidates are targeting people through other networks in which brokers may lack close personal ties to them, leading to agency loss. Finally, I argue that much of what I observe in Indonesia is like neither the core-voter nor the swingvoter model. This is largely because literature proposing these models was developed in settings that differ significantly from Indonesia. As a result, the dynamics of vote buying, or at least the targeting of vote buying, are distinctive in Indonesia.

\subsection{Contextual Factors}

As discussed in Chap. 1, vote buying doesn't occur in isolation. It is therefore important to take into account its institutional context. Our first challenge is to assess whether Indonesia's context differs from those under which the swing versus loyalist debate arose. In shining a light on context, this chapter compares Indonesia to several Latin American countries on which the literature is based, in terms of five contextual factors: (1) organisation of vote buying, (2) electoral system, (3) party base, (4) level of partisanship, and (5) voting systems.

\footnotetext{
${ }^{1}$ In this study, the word 'partisan' is sometimes used interchangeably with 'loyalist.' However, I should stress that there is still a significant difference between the two. I define the first in party terms and the second in candidate terms. However, as I will argue later, given the nature of open-list PR which incentivises personal votes, candidates will 'personalise' those who are loyal to their party in the sense that they will try to convert, or combine, their support for the party into personal support for them as individual candidates, over their co-partisan rivals.
} 
In terms of the structure of vote buying, much of the relevant literature is produced out of Latin America, which assumes party-based voting. ${ }^{2}$ In such cases, we should not only expect to see a high level of partisan voting, but the party machine will obviously be at the centre of political campaigns. Indonesia is virtually the opposite. This is important because both the swing- and core-voter models arose in settings where party machines have the capacity to monitor recipients' votes to ensure that bargains are kept. Political parties in Argentina are bottom-heavy organisations that embed themselves socially into communities, relying on an army of brokers linked to their local party structure (Stokes, 2007: 82-83; Kramon, 2013: 11). This organisation stems largely from the capacity of parties to control the distribution of state resources, enabling them to engage in deep interactions with voters (Auyero, 2001). The same holds true in other Latin American countries such as Mexico and Venezuela (Table 5.1). The assumption that typically underlies the literature on turnout buying (e.g. Nichter, 2008; Cox and McCubbins, 1986) is that parties are the only dominant actors in delivering benefits to their supporters. Even the norms of reciprocity model of Finan and Schechter (2012) require the existence of party operatives who can develop iterative relationships with voters and therefore channel rewards to reciprocal individuals. As Kramon (2013) pointed out, if political parties don't possess such personalised relationships with voters, vote buying is unlikely to be effective in encouraging a sense of moral obligation on the part of voters.

${ }^{2}$ Among others, Stokes (2005) provides evidence of this from Argentina. Enforcing votebuying bargains among swing or weakly opposed voters in Argentina, she argues, requires a well-organised party structure. Auyero (2001) and Levitsky (2003) also worked on Argentina, but focus on how party brokers function in everyday politics in the country. Similarly, in a later work, Stokes and her colleagues (2013) found evidence of the core-voter tendency in Argentina, Venezuela, and Mexico (as well as India), while emphasising the role of political parties as the main distributor of clientelist exchange. Similarly, Diaz-Cayeros and his colleagues $(2012,2016)$ found that political operatives in Mexico engage in more turnout buying (targeting passive loyalists to ensure they vote) rather than vote buying (favouring swing voters to sway their vote). The rationale is to avoid envy and jealousy among core constituents who might defect if not given benefits. Gans-Morse et al. (2014) generated valuable insights into the role of political context in Argentina and Brazil in shaping vote buying. In their model, given Brazil's strictly enforced compulsory voting and low machine support, party machines predominantly targeted swing voters rather than passive supporters. The point is that this literature on organisation of vote buying in Latin American countries focuses on political parties. 
Table 5.1 The different contexts of Indonesia and Latin American countries

\begin{tabular}{|c|c|c|c|c|}
\hline Countries & $\begin{array}{l}\text { Party } \\
\text { organisation }\end{array}$ & Electoral system & $\begin{array}{l}\text { Two-dominant } \\
\text { party system? }\end{array}$ & $\begin{array}{l}\text { Voting legally } \\
\text { compulsory? }\end{array}$ \\
\hline Indonesia & Weak & Open-List PR & No & No \\
\hline Argentina & Strong & Closed-List PR & Yes & Yes \\
\hline Venezuela & Strong & $\begin{array}{l}\text { Plurality + } \\
\text { Closed-List PR }\end{array}$ & Yes & No \\
\hline Mexico & Strong & $\begin{array}{l}\text { Plurality + } \\
\text { Closed-List PR }\end{array}$ & No & Yes \\
\hline Brazil & Weak & Open-List PR & No & Yes \\
\hline
\end{tabular}

Scholars of Indonesia have come to the conclusion that most parties in Indonesia are less organised as political machines, and they generally lack the capacity and organisational structure to penetrate local communities (Tomsa and Ufen, 2012; Berenschot, 2015). Compared to many countries in South America, the mobilisational strength of Indonesian parties is generally weak, and they are hardly involved in any kind of constituency service. In the conventional literature on vote buying, constituency service plays a significant role in increasing interactions between parties and voters (e.g. Auyero, 2001; Diaz-Cayeros et al., 2016). This is largely because, Berenschot (2015) argues, the distribution of state resources in Indonesia is largely not under the control of political parties, but instead in the bureaucracy, which has maintained significant discretionary power since the authoritarian period. As Berenschot (2015: 560) put it with regard to Latin America, "the degree of party control over the distribution of state resources seems to constitute an important contrast with Indonesia." This helps explain why most Indonesian parties are largely invisible at the grassroots and therefore lack the requisite capacity and organisational structure to engage with voters.

Put in a nutshell, the literature on the swing- and core-voter models arises in a context where party machines are both active in, and capable of, mobilising voters. Accordingly, the main organisational vehicle for vote buying in Latin America is parties. In Indonesia, by contrast, parties are largely inactive and inert, and it is individual candidates who run grassroots campaigns, including clientelist mobilisations.

Another difference with a lot of the Latin American cases on which the literature is based is the electoral system. In many countries in that region, 
MPs are elected through closed-list proportional representation and the remainder are elected by plurality rules (Table 5.1). Under the closed-list system, candidates rely primarily on party reputation, and competition primarily occurs as disputes between parties (Mainwaring, 1991). It therefore makes sense to target partisan voters and geographically discrete base areas to mobilise turnout. In this context, as Gans-Morse and his colleagues (2014: 417) put it, because parties and candidates have different electoral bases, they "don't directly compete to provide clientelist rewards to the same citizens" (italics in original).

Indonesia, by contrast, provides a completely different picture. Indonesia has adopted open-list elections. How does this difference make the logic of vote buying different in the Indonesian case? One obvious difference is that candidates need to rely on personal networks rather than the party. The open-list PR incentivises a personal vote and makes parties less relevant, which in turn lead elections to be more candidate-centric. Vote-seeking politicians wage highly personal campaigns, with little reference to their party platforms or policy positions. They also build personal campaign teams, independent of party structures. An overwhelming majority of candidates across the political spectrum, across distinct strata of legislative assemblies, rely on informal non-party organisations of brokers-known as tim sukses (success teams) - to mobilise voters. Since party structures are contested among other individuals in the party list, candidates cannot rely exclusively on them. This is obviously different from the context which has given rise to the dominant literature on vote buying or turnout buying in Latin American settings where political parties are well organised and socially embedded (e.g. Stokes, 2007; Diaz-Cayeros et al., 2016). While the literature conventionally assumes that brokers are "agents of a political party" (Holland and Palmer-Rubin, 2015: 1187), brokers in Indonesia are the soldiers of individual candidates. In Indonesia, candidates require their brokers to perform multiple tasks, ranging from constituency mobilisation, organising campaign rallies, distributing campaign paraphernalia, and delivering cash to voters.

Moreover, rather than winning the majority or large plurality of the votes that parties or candidates pursue in various Latin American countries, in Indonesia's open-list multi-member districts, a small proportion of the electorate can decide candidates' electoral fate. As already discussed in Chap. 1, given this system allows voters to determine which among a party's candidates are elected, it only requires candidates - provided they, their party, and their fellow party candidates have collectively won enough 
votes to gain one seat - to win just enough voters to beat their co-partisans. The marginal value of each voter collected through vote-buying strategies can be high enough to clinch victory. Nurul Arifin of Golkar colourfully talked of "the 2014 elections [being] like the civil war in Syria. Brothers are battling each other. The sword used in the battle is money to kill their own brothers" (Merdeka.com, 28 April 2014). She pointed her finger on the open-list PR's effect of making candidates of the same party fight each other. For Nurul, the only way to beat co-partisans is by outspending one's internal party rival in terms of distributing cash to voters; she claimed not to participate in vote buying and attributed her defeat to that fact (Merdeka.com, 28 April 2014).

Having discussed the first two distinguishing features of Indonesia's political environment relative to several Latin American countries, we now turn to reviewing the degree of partisan closeness in the two regions. Much of the debate on vote-buying strategies has arisen in contexts where levels of voter partisanship are higher than in Indonesia. Table $5.2 \mathrm{com}$ pares the level of partisanship in Indonesia with other countries (excluding Western countries) that have more or less adopted the Comparative Study of Electoral Systems (CSES) questions on partisanship. The most recent measure of mass partisanship in Indonesia conducted by my polling institute Indikator in February 2019 is 10.1\%, far below the average level (49\%).

With regard to the level of mass partisanship, Indonesia is different to Venezuela, Mexico, and Argentina and others, from which comparative literature on turnout buying has been produced, where levels of partisanship are relatively high. In such cases, the prospects of victory are much better for parties that simply target their partisan supporters with material inducements. This contrasts sharply with Indonesia where voters produce low scores on party identification. ${ }^{3}$ The country's condition of low party identification is similar to Brazil, where the recipients of largesse are predominantly swing voters (Nichter, 2010; Gans-Morse et al., 2014).

Figure 5.1 reveals the total percentage of Indonesians who reported feeling close to any party from 1999 to 2015 . The percentage between July 1999 and November 2004 exceeded 50\%, reflecting the decline of the early enthusiasm that accompanied the transition to democracy and Indonesia's first post-Suharto elections in June 1999, but there was a further sharp decline in mass partisanship from December 2004 to December

\footnotetext{
${ }^{3}$ For further discussion on the aggregate level of mass partisanship in Indonesia, see Chap. 4.
} 
Table 5.2 Party closeness across the world ${ }^{a}$

\begin{tabular}{|c|c|c|c|c|c|c|c|c|}
\hline Country & $\%$ & $\mathrm{~N}$ & Country & $\%$ & $\mathrm{~N}$ & Country & $\%$ & $\mathrm{~N}$ \\
\hline Asia & & & Ecuador 2013 & 32 & 1200 & Benin 2012 & 38 & 1200 \\
\hline Indonesia 2014 & 15 & 1210 & Nicaragua 2013 & 47 & 1000 & $\begin{array}{l}\text { Cote d'Ivoire } \\
2013\end{array}$ & 54 & 1200 \\
\hline Vietnam 2005 & 81 & 1200 & Mexico 2013 & 34 & 1200 & Botswana 2012 & 63 & 1200 \\
\hline India 2005 & 47 & 5178 & $\begin{array}{l}\text { Dominican Rep } \\
2013\end{array}$ & 59 & 1000 & $\begin{array}{l}\text { Burkina Faso } \\
2012\end{array}$ & 63 & 1200 \\
\hline Thailand 2006 & 28 & 1546 & Panama 2013 & 43 & 1000 & Burundi 2012 & 68 & 1199 \\
\hline $\begin{array}{l}\text { Philippines } \\
2005\end{array}$ & 42 & 1200 & Uruguay 2013 & 58 & 1200 & Cameroon 2013 & 41 & 1200 \\
\hline $\begin{array}{l}\text { Bangladesh } \\
2005\end{array}$ & 60 & 3176 & Chile 2013 & 25 & 1200 & Cape Verde 2011 & 60 & 1208 \\
\hline Japan 2007 & 75 & 992 & Paraguay 2013 & 71 & 1200 & Egypt 2013 & 22 & 1200 \\
\hline $\begin{array}{l}\text { South Korea } \\
2006\end{array}$ & 61 & 1060 & Honduras 2013 & 59 & 1000 & Ghana 2012 & 59 & 2400 \\
\hline Taiwan 2006 & 61 & 1587 & Africa & & & Guinea 2013 & 57 & 1200 \\
\hline Mongolia 2006 & 90 & 1211 & Uganda 2012 & 73 & 2400 & $\begin{array}{l}\text { Mozambique } \\
2012\end{array}$ & 71 & 2400 \\
\hline Pakistan 2005 & 31 & 2654 & Tanzania 2012 & 84 & 2400 & Namibia 2012 & 69 & 1200 \\
\hline Americas & & & Zimbabwe 2012 & 64 & 2400 & Niger 2013 & 80 & 1200 \\
\hline Argentina 2013 & 26 & 1200 & Zambia 2012 & 49 & 1200 & Nigeria 2012 & 45 & 2400 \\
\hline Bolivia 2013 & 23 & 1200 & Kenya 2011 & 58 & 2399 & Senegal 2013 & 60 & 1200 \\
\hline Colombia 2013 & 26 & 1200 & Lesotho 2012 & 66 & 1197 & $\begin{array}{l}\text { Sierra Leone } \\
2012\end{array}$ & 73 & 1190 \\
\hline $\begin{array}{l}\text { Guatemala } \\
2013\end{array}$ & 15 & 1000 & Liberia 2012 & 68 & 1199 & $\begin{array}{l}\text { South Africa } \\
2011\end{array}$ & 60 & 2399 \\
\hline Brazil 2013 & 18 & 1204 & Madagascar 2013 & 30 & 1200 & Togo 2012 & 34 & 1200 \\
\hline Peru 2013 & 16 & 1500 & Malawi 2012 & 60 & 2407 & Algeria 2013 & 42 & 1206 \\
\hline Venezuela 2013 & 58 & 1200 & Mali 2012 & 41 & 1200 & Tunisia 2013 & 30 & 1200 \\
\hline $\begin{array}{l}\text { El Salvador } \\
2013\end{array}$ & 39 & 1200 & Mauritius 2012 & 26 & 1200 & & & \\
\hline $\begin{array}{l}\text { Costa Rica } \\
2013\end{array}$ & 28 & 1000 & Morocco 2013 & 20 & 1200 & Average & 49 & \\
\hline
\end{tabular}

Sources: Data from South and Central American countries are taken from the Latinobarometer 2013 (see http://www.latinobarometro.org/latOnline.jsp. Accessed 14 May 2016) while those from African countries are provided from the Afrobarometer Round 5 2011-2012 (see http://afrobarometer.org/ online-data-analysis/analyse-online. Accessed 14 May 2016). Data from some Asian countries are taken from the Asian Barometer 2 (2005-2008) (see http://www.jdsurvey.net/jds/jdsurveyAnalisis.jsp?ES_ $\mathrm{COL}=101 \&$ Idioma $=\mathrm{I} \&$ Seccion $\mathrm{Col}=06 \& \mathrm{ESID}=503$. Accessed 18 May 2016)

The question used in the Americas is "Is there any political party you feel closer to than others?" whereas in Africa it is: "Do you feel close to any particular political party?" The question used by the Asian Barometer is: "Among the political parties listed here, which party if any do you feel closest to?"

${ }^{a}$ One important note is that partisanship in Vietnam which reached up to $84 \%$ clearly means something different under one-party rule than party identification in (multiparty) democracies 


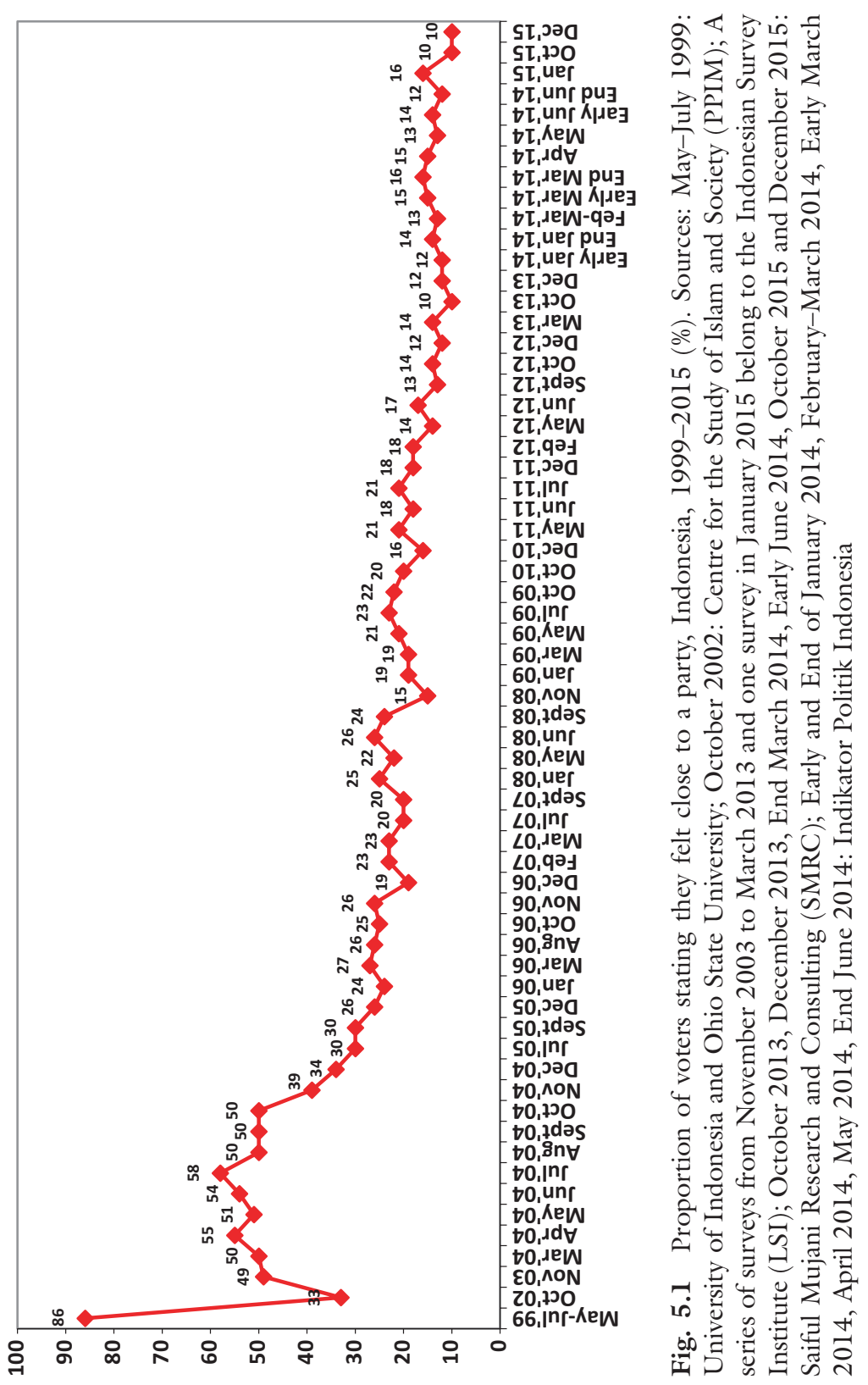


2005, with the aggregate level of partisan allegiance decreasing significantly to less than 30\%. Data from 2006 to 2010 exhibit increasingly weak party identification, with the level of party allegiance shrinking to an average of $22.2 \%$. Since 2011 , the degree of partisan affiliation of the electorate has fallen below $20 \%$. This low level of partisanship isn't superficial but is consistent.

One contextual factor that helps explain the level of partisan loyalty is the political party system. This is another difference between Latin American cases and Indonesia. Political scientists have long argued that party identification tends to be lower in multiparty systems (e.g. Thomassen and Rosema, 2009: 50). In two-dominant party systems, it tends to be higher. Countries like Argentina, Venezuela, and, to a lesser extent, Mexico, where much of the scholarly literature has identified turnoutbuying strategies, have two (or three) dominant parties that have decadesold historical roots. Parties have strong 'base areas' in these countries. Take, for instance, working-class areas in Argentina that have been voting for Peronists for years, or the long-time rural voter base of the Party of the Institutionalized Revolution (PRI) in Mexico.

The Indonesia case, however, is completely different. There has been a highly fragmented political party system in the country during the periods of competitive democracy (1950s and post-1998). As a result, only a few political parties in Indonesia enjoy a strong tradition of having partisan voters. PDI-P is perhaps the strongest example because there are some areas, especially in Central Java and North Sumatra, where people have been voting for the party for years, and where they can go back further and trace a history of the Indonesian Nationalist Party (PNI) dominance in the 1950s. As thoroughly discussed in Chap. 1, PDI-P has taken root among less pious Muslims, middle-lower-income groups, and religious minorities. Another party that deserves to be mentioned is $\mathrm{PKB}$, which has profited from close ties with the large socio-religious organisation, NU. It has consistently maintained its electoral base, especially within traditionalist communities in East Java. In general, however, most political parties in Indonesia don't have large or long-standing partisan bases.

Finally, much of this literature occurs in settings where voting is compulsory such as in Brazil, Argentina, and Mexico. Intuitively, compulsory voting increases the likelihood of parties targeting swing voters with payments, while the party loyalist strategy is more likely to develop in environments where voting in elections is optional. In places where voting is compulsory, parties logically will not fear non-participation by their own 
supporters because they may be subject to a penalty if they don't cast their votes. In such places, uncommitted swing voters who are willing to sell their votes are also more likely to participate. Empirical evidence, however, shows mixed results. Where compulsory voting laws are weakly enforced, as in Argentina, we can see evidence of turnout buying. In contrast, strict enforcement of compulsory voting encourages machines to target swing voters in Brazil (Gans-Morse et al., 2014; Nichter, 2010). In Indonesia, voting isn't compulsory. Under such circumstances, lukewarm supporters might not show up at the polls, if not given a benefit, making payments to such voters more likely. This gives rise to what Schaffer and Schedler (2007: 17-18) described as 'participation buying.'

Targeting party loyalists may help reduce uncertainty on the part of candidates regarding the final electoral results, as suggested in the preceding chapter. If a party loyalist bothers to turn out, the paying candidates can be reasonably sure that the voter will support them. However, it doesn't make this uncertainty completely disappear because the voter may, of course, choose a different candidate from the same party. Even if the party loyalist strategy is plausible in the context of non-compulsory voting, the emphasis on the personal vote under the open-list systems adopted by Indonesia means that candidates from the same party have to compete against each other for the support of a limited pool of partisan voters.

Overall, much of the scholarly literature analyses vote buying in the context of well-organised parties. It was also developed in a context where political parties are more prominent in organising election campaigns. Equally, the existing literature arose to describe environments where parties have some very strong 'base areas.' Indonesia, however, is different from these conditions. Vote-seeking politicians in Indonesia operate in a setting where the structure of vote buying is largely not party based, and political parties play, overall, a marginal role in election campaigns at the grassroots. The personalised nature of voting allows candidate to win only by gaining the support of a small slice of the electorate and in conditions where partisan ties are comparatively weak.

\subsection{Solving the Puzzles}

Having explained the contextual factors that affect the strategies candidates employ, we are now in a position to review the two puzzles stated at the outset of this chapter. In this section, I discuss the first puzzle about the feasibility for candidates to win by targeting only partisans, given their 
low absolute number and the strong intraparty competition among candidates for the support of such voters.

In an attempt to answer the first puzzle, I propose an explanation for how vote buying works in Indonesia that is distinctive from the swing- and core-voter models. I do so by drawing on the core-voter model, which emphasises turnout buying targeting party loyalists, but combine this analysis with a strong emphasis on personal networks. I argue that in Indonesia candidates and brokers actually intend to target partisan voters, but in reality, they mostly distribute patronage to people who are connected to them via personal networks. I call this combination of features a 'personal loyalist strategy.' Allowing a role for partisan voters, this strategy tries to personalise such voters by making them loyal not only to the party but also to the individual candidate within the party, as will be elaborated below.

The personal loyalist strategy, which combines targeting personalised party constituents with reliance on personal networks, is best suited to the context of an open-list PR system like Indonesia which provides incentives to politicians to rely on personal networks rather than the party, and in settings where the loyalties involved are largely personalised. The approach is built upon three distinct but interrelated strategies that candidates typically use. First of all, when they can, candidates start by targeting areas they think of as being 'party bases' on the basis of previous election returns. They believe these areas will likely yield greatest success in terms of personal votes. But, given there are only a few party strongholds, and these are typically contested among co-partisans, every candidate, starting long before the election, seeks to personalise their campaign in order to maximise their individual votes. They do so by reaching down to voters within this party base as individuals, including via party operatives whom they treat as personal clients.

Second, having realised that their party loyalists are limited in number and vulnerable to competition from internal competitors, candidates seek to expand their electoral base by using whatever personal connections they can mobilise. They start by determining their 'base' not only on the basis of previous electoral patterns but also based on their birthplace, kinship, religious, or ethnic ties, as I elaborate in more detail in the next section. In addition, candidates also choose areas where they have network connections or where they have in the past provided patronage and constituency service (Aspinall et al. 2017: 13). This is typically not enough, though. If they rely solely on their personal networks, candidates would fail to gain 
the votes they need to win. Recall that candidates running for nationallevel and provincial-level parliaments have to win hundreds of thousands of votes, depending on the density of the population.

Finally, in order to further enhance their electoral prospects, candidates seek to reach out to a greater number of voters through personal connections mediated by non-party brokers. These brokers expand beyond the party and the candidate's personal electoral base by providing additional support on the basis of their own clientelist and other personal networks. As Aspinall and his colleagues (2017: 5 ) nicely put it, "brokerage networks were a method for scaling up a candidate's personal patron-client networks to encompass a greater number of voters." Therefore, I argue that what matters here isn't the broker per se, but the size of the broker army who run vote-buying efforts on the basis of their heterogeneous networks. How large and strong the brokerage network a candidate has can determine whether that candidate wins more votes than his or her internal rivals.

At first sight, this personal loyalist strategy looks promising. With limited resources in hand and dealing with large constituencies, candidates strategically target only those they think will be most likely to support them personally. However, as presented in Chap. 7, most of the recipients simply take the money but vote according to their conscience. A senior journalist in Padang, West Sumatra, cited an analogy of hiring a person to climb coconut trees. He said giving money to voters is like when a coconut picker takes the salary, but declines to pick the coconuts (Sukri Umar, Interview 23 September 2014). ${ }^{4}$ Notwithstanding candidates' strong intentions to reward only people they think of as loyal supporters, this strategy cannot fully prevent 'leakage' or 'slippage' to people who don't repay them with support. ${ }^{5}$ This is largely because many of those candidates depicted as 'loyalists' are likely to defect, as will be explained in more detail in the following pages. The distinction between 'party base' and 'personal vote base' is thus blurred, as Aspinall and his colleagues (2017: 13) explain:

\footnotetext{
${ }^{4}$ This strategy isn't only unique in the Indonesian context. Cardinal Sin, Archbishop of Manila, for instance, is widely known for his advice by giving a famous analogy: "take the bait, but not the hook" (Schaffer, 2005; Hicken et al., 2017).

${ }^{5}$ It is striking that candidates keep thinking of such people as their 'base,' while they should know that a lot of them are only weakly connected to them. As I argue in Chap. 7, candidates actually understand that the targeting of vote buying is misdirected, but because their goal is only to obtain a narrow winning margin, they know that the strategy is still worthwhile.
} 
Overall, when candidates used terms suggesting core versus swing voters, they thus typically understood such terms in personal terms, rather than in terms of voters' identification with a party or program. They were talking about a clientele rather than a party core.

This brings us back to the seemingly paradoxical finding in my voter survey described in Chap. 4: while partisan voters are more likely to be targeted than non-partisans, in fact, most vote buying happens among uncommitted voters. This outcome, I argue, is a result of weaknesses of the strategy above that combines a party loyalist approach with reliance on personal networks. But why is the conceptual confusion? Why do candidates keep insisting they are targeting loyal voters, while the facts show that much of their spending is wasted on uncommitted voters who receive benefits but don't always reciprocate with their votes? Three preliminary explanations are offered at this stage: (1) candidates and brokers tend to exaggerate the number of partisan voters; $(2)$ they exhibit confusion about the concept of 'loyalty'; and (3) agency loss occurs, contributing to a large amount of targeting of uncommitted voters.

\subsubsection{Exaggerating the Numbers of Partisan, Loyalist Voters}

The first probable explanation for the gap is clear: many politicians across the political spectrum exaggerate the number of partisan voters in Indonesia. Many politicians find it hard to accept the reality that relatively few voters feel close to any political party in Indonesia today. As one of the leading public commentators on Indonesian political affairs, with regular national media exposure due in part to my position with the country's pre-eminent opinion survey organisations, LSI and Indikator, many political parties frequently invite me to discuss political trends and, especially, to explain survey data. When I present on the general decline in partisanship, party leaders often admit there is such a trend, but stubbornly reject the finding that as many as nine out of ten Indonesians express that they aren't close to any political party. They typically claim that the level of partisan loyalty isn't that low. Politicians not only express this denial in internal and closed discussions but also in public forums. In the lead-up to the 2014 election, I appeared on a prime-time television political programme with a party leader from the Islamist party, PPP. He expressed his strong disagreement with my survey findings, suggesting low scores on voters' psychological bonds with political parties. Similarly, in a confidential interview, 
one elected candidate from the traditionalist Islam party PKB suspected that many pollsters have consistently underestimated how many people feel close to political parties, especially his own party, by arguing:

It is difficult to believe that people who self-describe as being PKB loyalists are much fewer than those of the PKS. My party is closely associated with the largest Islamic organisation and it can be traced back in the history of NU dominance in Java during the 1955 elections... So weird. (Interview, 12 May 2014)

The tendency to exaggerate the number of partisan voters might help increase politicians' confidence in the context of competitive elections and ameliorate their anxiety about future election results, as discussed below. However, although many politicians exaggerate the number of partisan voters, overall, they typically agree that more Indonesians match the nonpartisan profile than are partisans. They understand that many voters don't have partisan attachments, but insist a significant proportion of the electorate still feel close to a party.

Another powerful example of exaggeration is provided by a unique set of polling data from low-level politicians and brokers. As previously explained, from September to October 2014, I surveyed 299 candidates and 900 brokers in four provinces (Appendix B). Figure 5.2 shows that, overall, respondents tended to overestimate the number of partisan, loyalist voters. The prompt is: "We would like to inquire further about the characteristics of voters in your area. Out of ten people in your area, ${ }^{6}$ approximately how many people who always vote in every election and would always vote for the party/candidate 7 you support?" Hence, voter loyalty here is defined in terms of turnout propensities and partisan closeness or loyalty to the candidate. While responses to this question were quite scattered, the modal answer-from either the surveyed candidates (featured in horizontal stripes within Fig. 5.2) or brokers (highlighted in vertical stripes) —was '7 out of 10.' No candidates said 'none,' whereas about $74 \%$ of candidates estimated the frequency of loyal voters in their regions at six out of ten or higher. Similarly, the overwhelming majority of brokers $(74 \%)$ claimed that of ten people in

\footnotetext{
${ }^{6}$ In my questionnaire, I used undefined 'wilayah' (area) which didn't specifically refer to electoral district or village or neighbourhood.

${ }^{7}$ Having used the wording 'the party/candidate,' the question problematically conflated partisanship with a sense of loyalty to the candidate. Unfortunately, this part of the survey was designed before I decided to focus on the issue of partisanship in my follow-up research.
} 


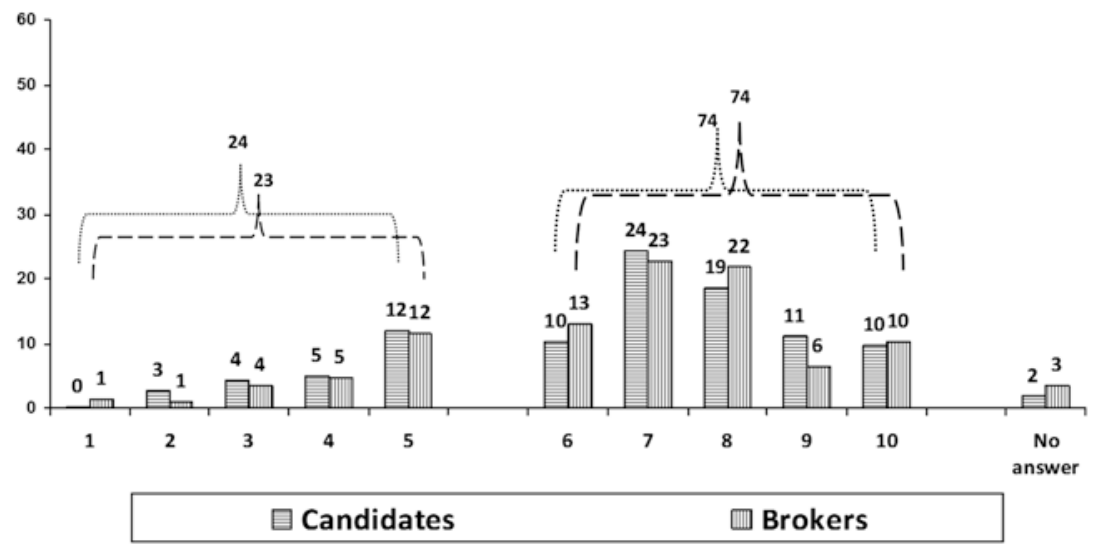

Fig. 5.2 Political actors' perceptions of the frequency of loyal voters (\%). The question used is "In your region, out of ten typical voters how many people would who always vote in every election and would always vote for the party/candidate you support?" Source: My survey of low-level politicians and brokers, 30 September-25 October 2014

their neighbourhoods, six to all could be categorised as certain loyal voters. Only $23 \%$ of brokers estimated the frequency of perceived loyalists at one to five out of ten people in their neighbourhoods. This response is, of course, a huge exaggeration, though presumably some bravado was involved.

Before we move on, it is worth pausing to consider one more source of information to check whether candidates and brokers really are exaggerating the number of partisan voters (so far, I have only relied on self-reported levels of partisanship in surveys). One way to think about party loyalist voters is that they are those voters who faithfully return to their party at every election. Accordingly, I provide additional data by estimating the number of partisan voters based on those who supported a party in the 2009 legislative election and voted for the same party in $2014 .^{8}$ It must be

\footnotetext{
${ }^{8}$ The question reads: "Did you vote in the 2009 elections?" If the respondent responded affirmatively, we asked "Which party did you vote for?" The interviewer showed the list of political parties competing in the 2009 election. In the survey, we also asked: "Did you vote in the 2014 elections?" If yes, we asked "Which party did you vote for in the 2014 elections?" The interviewer showed the list of political parties competing in the 2014 election to the respondents.
} 
noted, however, that the number of national parties competing in these elections didn't remain the same (38 parties contested in 2009 compared with 12 parties in 2014). It means my estimate is only able to measure the loyalty of voters whose parties competed in both 2009 and 2014. This calculation cannot also exclude 2014 first-time voters who were, of course, ineligible to vote in 2009.

My strategy is simple: drawing from my post-election survey in 2014 (see Appendix A), I ran cross-tabulation between those who reported their party choices in 2009 and 2014 to get the detailed percentages of party loyalists and non-loyalists in each party. As shown in Table 5.3 (look especially at the numbers without brackets), the proportion of party loyalists, by this measure, varies considerably. Only $20.7 \%$ of voters who sup-

Table 5.3 Estimated numbers of party loyalists in Indonesia measured by voters who voted for the same party in two consecutive elections, 2009 and 2014

\begin{tabular}{|c|c|c|c|c|}
\hline & \multicolumn{2}{|c|}{2009 election results (baseline) } & \multicolumn{2}{|c|}{$\begin{array}{l}\text { Having voted for the party in } \\
2009 \text { did you vote for it again in } \\
2014 ?^{a}\end{array}$} \\
\hline & $\begin{array}{l}\text { As percentage of total } \\
\text { number of valid votes } \\
(\%)\end{array}$ & $\begin{array}{l}\text { As percentage of } \\
\text { fixed voters list } \\
(\%)\end{array}$ & res & $\begin{array}{l}\text { No/Don't } \\
\text { know/No } \\
\text { answer }\end{array}$ \\
\hline $\mathrm{PKB}$ & 4.9 & 3.0 & $48.5[1.5]$ & $51.5[1.5]$ \\
\hline PKS & 7.9 & 4.8 & $49.1[2.4]$ & $50.9[2.4]$ \\
\hline PDI-P & 14 & 8.5 & $59.6[5.1]$ & $40.4[3.4]$ \\
\hline Golkar & 14.4 & 8.8 & $52.6[4.6]$ & $47.4[4.2]$ \\
\hline Gerindra & 4.5 & 2.7 & $53.3[1.4]$ & $46.7[1.3]$ \\
\hline $\begin{array}{l}\text { Democratic } \\
\text { Party }\end{array}$ & 20.8 & 12.7 & $20.7[2.6]$ & $79.3[10]$ \\
\hline PAN & 6 & 3.7 & $42.5[1.6]$ & $57.5[2.1]$ \\
\hline PPP & 5.3 & 3.2 & $44.4[1.4]$ & $55.6[1.8]$ \\
\hline Hanura & 3.8 & 2.3 & $69.2[1.6]$ & $30.8[0.7]$ \\
\hline PBB & 1.8 & 1.1 & $8.3[0.1]$ & $91.7[1.0]$ \\
\hline PKPI & 0.9 & 0.5 & $0[0]$ & $100[0.5]$ \\
\hline Others & 15.6 & 9.5 & $0[0]$ & $100[9.5]$ \\
\hline Total & 100 & 60.8 & $36.6[22.2]$ & $63.4[38.5]$ \\
\hline
\end{tabular}

Source: The data on those who supported a party in the 2009 legislative election and voted for the same party in 2014 are collected from my post-election survey, 22-26 April 2014, while the data on the 2009 election results are taken from the Indonesia's Electoral Commission (Komisi Pemilihan Umum, KPU)

${ }^{2}$ The first figure in each of the last two columns is an estimate based on the total number of valid votes; the second number is based on the DPT 
ported the Democratic Party in 2009 voted for the party again in 2014 . This is largely because the party's popularity dropped significantly in 2014 , following a series of party corruption scandals (Aspinall et al., 2015). Parties that were relatively successful at maintaining their voters' loyalty were Hanura, PDI-P, Gerindra, and Golkar. Note that the sampling frame of my voter-level data isn't only limited to the total number of valid votes casted in the election but all registered voters including those who didn't turn out on voting day. Accordingly, to produce an estimate of the proportion of eligible voters who are loyal to a particular party, I also convert these percentages of party loyalists and non-loyalists in each party into percentages of the fixed voter list or Daftar Pemilih Tetap-DPT (look for the number in brackets). I prefer to divide by the DPT rather than by the total number of valid votes because these data are based on the postelection survey whose target population weren't only those who cast their votes on election day but also those who didn't turn out.

Though using this rather weak measure of party loyalty (voting for the same party in two consecutive elections), the conclusion still holds that the number of party loyalists in Indonesia is relatively low. Only $22.2 \%$ of the total electorate voted in 2014 for the same party they had supported in 2009. Of votes cast, $36.6 \%$ were cast by people voting for the party they had supported in 2009. There isn't a huge difference between these figures, especially the first one, and the number of voters who reported themselves as being close to a party (15\%) shortly after the 2014 election isn't significant, implying that the estimated proportion of party loyalists in Indonesia lay somewhere between $15 \%$ and $22 \%$ at that time. If we could compile data about voter loyalty based on those who faithfully return to their party in every election (i.e. 1999, 2004, 2009, and 2014), I suspect the percentage of party loyalists would be significantly lower than $22.2 \%$. In short, a range of between $15 \%$ and $22 \%$ of party loyalists provides strong evidence that politicians and brokers make exaggerated claims about the number of such voters.

\subsubsection{The Amorphous Concept of Loyalty}

A second reasonable explanation for why so much cash ends up in the hands of voters who aren't especially attached to any particular party, despite strong desires of politicians and brokers to target loyal voters, is the obscurity of the concepts of voter loyalty and base areas in the Indonesian context. Though they make bold claims about how many vot- 
ers are loyal, in fact, many politicians and brokers use amorphous criteria in defining loyal and non-loyal voters.

Using a hypothetical scenario which is developed from Stokes and her collaborators (2013), this study asked the surveyed candidates and brokers about the effect of voter types (defined by turnout propensities, partisan affiliation, and loyalty to the candidate) on attracting benefits. The sum of their responses to this question is then classified based on their political parties. Table 5.4 shows that I found surprisingly little variation across

Table 5.4 Variations across political parties in targeting strategies

\begin{tabular}{|c|c|c|c|c|c|}
\hline \multirow[t]{2}{*}{$\begin{array}{l}\text { Party } \\
\text { affiliations }\end{array}$} & \multirow[t]{2}{*}{$\begin{array}{l}\text { Which group will the success } \\
\text { team direct more assistance to? }\end{array}$} & \multirow[t]{2}{*}{$\begin{array}{l}\text { Percent } \\
(\%)\end{array}$} & \multirow[t]{2}{*}{$\begin{array}{l}\text { Standard } \\
\text { error }\end{array}$} & \multicolumn{2}{|c|}{$\begin{array}{l}95 \% \text { confidence } \\
\text { interval }\end{array}$} \\
\hline & & & & Lower & Upper \\
\hline \multirow{2}{*}{ NasDem } & Loyal voters & 93.86 & 3.68 & 81.35 & 98.17 \\
\hline & Swing voters & 5.16 & 3.41 & 1.37 & 17.61 \\
\hline \multirow[t]{2}{*}{ PKB } & Loyal voters & 86.96 & 4.51 & 75.33 & 93.57 \\
\hline & Swing voters & 12.42 & 4.48 & 5.94 & 24.14 \\
\hline \multirow[t]{2}{*}{ PKS } & Loyal voters & 82.76 & 9.65 & 56.00 & 94.77 \\
\hline & Swing voters & 7.63 & 5.50 & 1.76 & 27.63 \\
\hline \multirow[t]{2}{*}{ PDI-P } & Loyal voters & 63.69 & 5.56 & 52.25 & 73.76 \\
\hline & Swing voters & 29.28 & 5.24 & 20.12 & 40.49 \\
\hline \multirow[t]{2}{*}{ Golkar } & Loyal voters & 77.13 & 5.92 & 63.58 & 86.70 \\
\hline & Swing voters & 20.97 & 5.74 & 11.86 & 34.36 \\
\hline \multirow[t]{2}{*}{ Gerindra } & Loyal voters & 79.30 & 7.46 & 61.08 & 90.34 \\
\hline & Swing voters & 19.16 & 7.42 & 8.47 & 37.77 \\
\hline Democratic & Loyal voters & 87.94 & 5.33 & 73.11 & 95.14 \\
\hline Party & Swing voters & 5.18 & 2.90 & 1.69 & 14.82 \\
\hline \multirow[t]{2}{*}{ PAN } & Loyal voters & 69.38 & 9.71 & 48.03 & 84.75 \\
\hline & Swing voters & 21.11 & 8.34 & 9.11 & 41.69 \\
\hline \multirow[t]{2}{*}{ PPP } & Loyal voters & 82.36 & 13.50 & 42.97 & 96.66 \\
\hline & Swing voters & 17.04 & 13.51 & 3.05 & 57.29 \\
\hline \multirow[t]{2}{*}{ Hanura } & Loyal voters & 78.91 & 11.81 & 48.15 & 93.78 \\
\hline & Swing voters & 16.04 & 9.75 & 4.41 & 44.18 \\
\hline \multirow[t]{2}{*}{$\mathrm{PBB}$} & Loyal voters & 92.25 & 6.30 & 67.85 & 98.53 \\
\hline & Swing voters & 7.75 & 6.30 & 1.47 & 32.15 \\
\hline \multirow[t]{2}{*}{ PKPI } & Loyal voters & 49.24 & 34.98 & 5.86 & 93.80 \\
\hline & Swing voters & 50.76 & 34.98 & 6.20 & 94.14 \\
\hline
\end{tabular}

Source: My survey of low-level politicians and brokers, 30 September-25 October 2014

The question used is: "Imagine this situation. There is a candidate together with his/her campaign team who offered 10 social assistance packages to mobilise voters. In reality, the candidate's success team member had 40 neighbours in need of social assistance. According to you, which group of voters will the campaign team direct more assistance to?" 
political parties in the targeting strategies. Almost all candidates from different political parties, except PKPI, said they would prioritise 'loyal voters.' In fact, more than $80 \%$ of respondents said this in most cases.

But one interesting point is that the figure for the PDI-P isn't that high, despite that party actually having a strong party base. This corresponds with the narrative from PDI-P candidates that their support base is truly loyal and solid so they don't need to seduce them with payments to attend polling places. Ahmad Basarah, a successful PDI-P candidate, for instance, claimed that he didn't distribute money within his own party base and only paid for snacks, drinks, and cigarettes for the many informal meetings he held with his loyalists (Interview, 21 April 2014). This claim, however, contradicts what we found from voter surveys. As discussed in Chap. 4 , those who felt close to PDI-P were significantly more likely than the average voter to be exposed to vote buying. However, the general rule remains the same: candidates and brokers tended to say they focus on mobilising their own party bases. This is particularly the case when they were asked about their strategies in the 2014 election. When we divided locales into three categories: party base, opposition base, and swing districts, their first priority was consistently to exploit the 'party base' (Table 5.5).

Table 5.5 In 2014, where did you distribute largess to get votes? (\%)

\begin{tabular}{|c|c|c|c|c|}
\hline & $\begin{array}{l}\text { In area which } \\
\text { always support } \\
\text { my party (party } \\
\text { base) }\end{array}$ & $\begin{array}{l}\text { In swing area where } \\
\text { the voting behaviour } \\
\text { cannot be determined }\end{array}$ & $\begin{array}{l}\text { In area which always } \\
\text { support other parties } \\
\text { (party opponent } \\
\text { base) }\end{array}$ & $\begin{array}{l}\text { Don't } \\
\text { know/No } \\
\text { answer }\end{array}$ \\
\hline NasDem & 52.54 & 9.60 & 0.20 & 37.66 \\
\hline PKB & 64.63 & 14.54 & 3.42 & 17.41 \\
\hline PKS & 27.23 & 18.24 & 7.97 & 46.56 \\
\hline PDI-P & 39.69 & 24.21 & 3.45 & 32.64 \\
\hline Golkar & 65.86 & 20.80 & 3.07 & 10.26 \\
\hline Gerindra & 69.72 & 6.79 & 9.48 & 14.01 \\
\hline $\begin{array}{l}\text { Democratic } \\
\text { Party }\end{array}$ & 67.19 & 24.78 & 0.04 & 7.99 \\
\hline PAN & 66.04 & 13.84 & 3.48 & 16.64 \\
\hline PPP & 88.13 & 0.83 & & 11.04 \\
\hline Hanura & 78.71 & 4.50 & 3.87 & 12.92 \\
\hline $\mathrm{PBB}$ & 86.76 & 2.91 & & 10.32 \\
\hline PKPI & 49.24 & 49.24 & & 1.51 \\
\hline Don't know & 10.69 & & & 89.31 \\
\hline
\end{tabular}


As shown in Table 5.5, candidates from PKS and NasDem and their political operatives tended to be more reluctant to report their targeting strategies in 2014. The same holds true in the case of PDI-P candidates, showing that 'only' $39.69 \%$ of the respondents from the party's candidates and their brokers reported targeting their own base, while around a third of them were unwilling to respond to the question. However, the big picture is consistent: the so-called party base is the preferred target. ${ }^{9}$ Most politicians and their brokers prioritised their party bases because they thought their potential vote was higher there.

This is quite a striking result, not least because Tables 5.4 and 5.5 highlight evidence of targeting partisan voters in parties that don't really have a tradition of having partisan loyalist voters. As noted earlier, Indonesia has very few political parties which have enjoyed consistent political support across several elections. It is especially striking that candidates from NasDem claimed to be targeting their own loyal supporters, while in fact the party had just been officially launched in 2011 and was running for the first time in 2014. Hanura and Gerindra were quite similar. They competed for the first time in 2009 and their shares of the vote were quite minimal at the time. Accordingly, these three parties must have had only very small numbers of truly 'loyal' partisan voters.

Note that in the lead-up to the 2014 election, partisan voters constituted only $15 \%$ of the total electorate (see Chap. 4). Even if we use another criterion of voter loyalty based on those who voted for the same party in 2014 and 2009 , we have only around $22 \%$ of the total electorate. These small numbers of party loyalists, to be sure, are highly contested, with internal party rivals competing for their support in the context of an open-list PR system which intensifies intense intraparty contests.

There is a widely held assumption that candidates who are placed high on party lists tend to rely on party members in their success teams because they are usually heads of party branches or close to key party leaders. Intuitively, these candidates will also tend to target party loyalists more than they target unattached voters. Table 5.6 confirms this practitioner's

\footnotetext{
${ }^{9}$ Interestingly, candidates and brokers from Central Java and North Sulawesi were more likely to target party loyalists than those from West Sumatra and East Java. This is perhaps related to the evidence that partisan voters are more likely to be found in Central Java and North Sulawesi (see Chaps. 1 and 4).
} 
Table 5.6 Candidates' position on the party list and targeting strategies (\%)

\begin{tabular}{lccc}
\hline $\begin{array}{l}\text { Party } \\
\text { list }\end{array}$ & $\begin{array}{l}\text { In area which always } \\
\text { support my party } \\
\text { (party base) }\end{array}$ & $\begin{array}{l}\text { In swing area where the } \\
\text { voting behaviour cannot be } \\
\text { determined }\end{array}$ & $\begin{array}{l}\text { In area which always } \\
\text { support other parties (party } \\
\text { opponent base) }\end{array}$ \\
\hline 1 & 74.63 & 21.95 & 3.43 \\
2 & 87.69 & 6.30 & 6.01 \\
3 and & 73.48 & 22.89 & 3.63 \\
4 & 67.65 & 25.29 & 7.06 \\
5,6, & & & \\
and 7 & 73.47 & 26.49 & 0.03 \\
$>7$ & & & \\
\hline
\end{tabular}

Chi-square tests

\begin{tabular}{llll}
\hline & Value & $d f$ & Asymp. Sig. (2-sided) \\
\hline Pearson chi-square & 27.444 & 8 & 0.001 \\
\hline
\end{tabular}

Note: The 'refuse to answer' and 'don't know' options were excluded from the analysis

rule of thumb. The bivariate test with Pearson's chi-square shows that the relationship between candidates' position on the party list and targeting strategies reaches the 0.05 level of statistical significance.

\subsubsection{Agency Loss}

In addition to the two above factors, the problem of targeting gets worse as a result of agency loss. As discussed earlier, candidates and brokers tend to inflate the number of partisan voters because they actually conflate those who are loyal to the party and those who are perceived to be personally loyal to the candidate. However, this isn't the only problem. Brokers clearly have an interest to overstate their capacity to sway people to support their party/candidate. Brokers frequently try to convince their candidates they have leverage in a particular subdistrict or village, within an ethnic organisation, or inside some other social network (Warburton, 2016: 343), but in fact their claims are often baseless. That is similar to the point made by Stokes et al. (2013), who argue that brokers have an incentive in exaggerating their followers in order to extract rents. They argue that party leaders tend to favour targeting swing voters, but they are unable to control their party brokers who instead direct benefits to core supporters for rent extraction purposes. Such difficulty in controlling and 
monitoring brokers can be a source of substantial 'leakages' which can help explain why many supposedly 'loyal' voters targeted by machines in fact don't reciprocate with their votes: in the context of an overall turnoutbuying strategy brokers might (reversing the story suggested by Stokes et al., 2013) exaggerate the number of loyal voters to ensure a greater amount of money and goods flow through their hands.

But why do candidates also exaggerate? It is reasonable to assume that candidates cannot be easily fooled by their brokers. As we shall see, there is plenty of evidence that candidates do know that a lot of people who are identified through personal networks, including those who are provided by their brokers, are only weakly connected to them. They also fear that such voters aren't immune to approaches by brokers for rival candidates, and they generally also worry that their brokers might trick them for rent extraction purposes. Even so, vote buying remains an attractive investment for most candidates. We shall see in Chap. 7 that part of the explanation is that they still believe that there are a sufficient proportion of the electorate whose voting decisions are largely influenced by handouts, and this is more than enough to constitute narrow winning margins. Given the ballot secrecy that is strongly enforced in Indonesia (see Chap. 6), many candidates, especially those who won a seat, seemed to be lenient if their brokers didn't deliver all the votes they promised as long as they were successful in securing enough personal votes to win. Most candidates are still convinced that among those being targeted by their brokers, a proportion of recipients will reciprocate with votes. One prominent national politician from $\mathrm{PKB}$, for instance, was quite relaxed about his broker performance. Despite handing out a large sum of money in 450,000 envelopes containing cash, he yielded 'only' around 123,000 votes and still got elected. He explained:

There is a consensus among candidates: If you only get a third of the total envelopes you distribute, that's a good result. First, set your target. If you want to receive 100,000 votes to get elected, you must distribute envelopes tripling that. That's the rule. (Interview, 20 April 2014)

Needless to say, many losing candidates still get quite upset if their brokers fall far short of their targets. Regardless of the outcome, most candidates actually realise that in the context of open-list PR systems, they rely heavily on brokers to reach out voters in search of personal 
votes and so "stand out in a crowded field of co-partisans" (Shugart, 2001: 183). As discussed in Chap. 6, when candidates started to exhaust the supply of partisans or those who have close personal ties to them, they often rely on their brokers to determine which voters should be targeted. These people who are selected through personal networks are loosely connected to ideological proximity to the party and may lack personal relationships with the candidate. Accordingly, the potential for leakage-defined as those who receive payment yet don't reciprocate with votes-is great. However, in a context of competitive elections like Indonesia where minor changes in voter support can make a difference to the outcome (see Chap. 7) and multiple candidates engage in vote buying, anxious candidates have little option but to rely on brokers to win the election. They need these brokers to expand their voter base.

In addition, candidates typically acknowledge that it is almost impossible to fully eliminate broker predation and to enforce voter compliance. Candidates are generally aware that to make vote-buying work, they need skilled and reliable brokers to distribute rewards to the voters they believe most likely to support them in return. In general terms, to do so, candidates would require a double-layered control mechanism to monitor both brokers and voters. The first layer of the mechanism aims primarily to discipline brokers in order to make vote buying more efficient and reduce incentives for broker predation. The second layer is devoted to dealing with the problem of voter compliance. In order to help detect who has kept with the bargain and enforced the deal, politicians require what Stokes (2005: 322) called "tentacle like organisational structures." Yet, in practice, most candidates in Indonesia fail to build impressive monitoring structures (Chap. 6). Equally, brokers have weak mechanisms to monitor their voters to ensure that they vote for the candidate. Accordingly, despite such a strong desire among candidates and brokers to appeal to constituents who they think will reciprocate, they mostly end up distributing resources to uncommitted voters. As the quotation from the PKB politician above suggests, they learn to live with considerable mistargeting and wastage.

To sum up the discussion, political machines plausibly exaggerate the proportion of loyalist voters. This is partly because the concept of loyal voters in the Indonesian context is ambiguous and obscure. When candidates and brokers routinely talk about targeting loyalist voters, they not 
only refer to fixed party loyalties but also judge loyalty in terms of personal networks. ${ }^{10}$ This confusion leads to misdirection of targeting strategies. Instead of directing campaign resources towards constituents who are truly loyal, most brokers end up being distributed to unattached voters, who don't necessarily reciprocate with support. Moreover, agency loss also produces the unreliability of voters who are identified through personal networks. These factors in combination-exaggerated claims about the number of loyalists, confusion of personal connections with loyalty, and poor voter compliance with clientelist deals-contribute to the large amount of targeting of uncommitted voters.

\subsection{Dimensions of Personal Networks}

Having understood the reasons why targeting goes astray, the subsequent question is: what sort of person does get targeted for the payments? What criteria are used in targeting those whom the candidates and brokers claim to be 'loyalists'? In seeking an answer, one quickly gets bogged down in a classic anthropological conundrum: the responses candidates and brokers provide in survey interviews may not be honest answers, or at least not responses that satisfy the observer (Eder, 1991: 153). But we can seek a satisfactory explanation from qualitative research. From my field interviews, it was obvious that when candidates claimed to be targeting 'loyalists,' they typically referred to more personalised rather than strictly party-based relationships.

As discussed in an earlier section of this chapter, context really matters in explaining this ambiguity. Given the nature of the non-party organisation of vote buying in Indonesia, candidates and brokers appear to extend the definition of loyal voters to include persons who are 'close' to them by virtue of brokerage networks, kinship, and patronage loyalties and other informal connections. In interviews, candidates and brokers always talked

${ }^{10}$ The point that, in practice, partisan and personal networks might be overlapping can be evident when political parties often recruit their supporters through personal or familial relationships. When a PDI-P candidate recruits a broker, this broker is likely to be from similar ideological and organisational networks as the candidate. Similarly, a PKB candidate typically mobilises brokers from the 'traditionalist' Islamic community in which the party was rooted. Then, the brokers are expected to target voters on the basis of nearness to their own personal networks. In other words, despite the salience of candidates' personal networks, to some extent, these networks should be situated within ideological, social-cultural, and religious milieus linked to their parties. 
about targeting 'loyal voters' and 'base areas,' superficially sounding as though they were concerned with partisan loyalty and past voting patterns. However, when I pushed them and asked them what their 'basis' really was, it generally turned out to be about clientelism. ${ }^{11}$ For example, having a strong brokerage network in a particular village makes that area part of the 'base' of that candidate (Aspinall et al., 2017: 13). This is why, despite candidates and brokers claiming to be targeting loyal voters and base areas, they aren't truly pursuing a core-voter strategy as typically understood by scholars writing on other countries. Put differently, when candidates asked their brokers to exploit 'base areas,' they typically understand this phrase in personal rather than partisan terms (Aspinall et al., 2017: 13-14).

This is the main argument in the personal loyalist strategic logic I outline above. Candidates tend to be confused, and they wrongly think of personal loyalists as party partisans. The confusion over the definition of loyal voters provides suggestive evidence of the plausibility of my argument. Given the significance of personal connections in explaining targeting strategies, it is essential to better understand the various dimensions of personal networks in the Indonesian context.

One important foundation of personal networks in Indonesian electoral politics is areas where a candidate has close personal or familial connections. This typically includes the location of a candidate's birthplace, or where they grew up or lived, but can include other areas where they have family or marriage ties (e.g. a spouse's home village/subdistrict) (see Aspinall et al., 2017). When deciding on where to focus their campaign strategies, candidates generally draw in not only their immediate family but also to the greater family by using "bilateral kinship links from both parental lines and following the various branches of the family tree as far as they went" (Sumampouw, 2016: 326). For instance, Anton Miharjo who worked for Lathifah Shohib (a PKB candidate) told me a story. Lathifah is a distant cousin of the late Abdurrahman Wahid the former President of Indonesia and the grandson of the founder of $\mathrm{NU}, \mathrm{KH}$ Hasyim Asy'ari. Lathifah who lived in Malang was a simple teacher and unable to mobilise a large campaign because of her limited finances. To

\footnotetext{
${ }^{11}$ Aspinall and his colleagues (2017) also had similar experiences when inquiring about candidates' targeting strategies. As Aspinall et al. (2017: 12) put it, most candidates claimed "they prioritized voters they considered to be their basis ... believing this would yield greater return on their efforts."
} 
attract loyalty from PKB and NU cadres, she hired a number of buses to travel to Wahid's tomb in Jombang and asked those who accompanied her from Malang to take the baiat or oath of allegiance to help win her campaign. Indeed, she finally got elected. Her campaign team organiser said to me, "Aside from the living, we also make use of the dead" (Interview, Anton Miharjo, 2 May 2014).

In ethnically and religiously divided areas, personal bases and networks can be also created on the basis of primordial affiliations. Ethnic associations in North Sumatra, for instance, played an important role in mobilising electoral support for candidates. Religious networks are equally important for many candidates. Candidates from the Batak ethnic group, for example, usually take advantage of marga (clan) networks to reach voters from the same clan (Interview, Firman Jaya Daeli, 21 July 2014). The same holds true in the case of many parts of eastern Indonesia where fam, derived from the Dutch familienaam, and equivalent to marga, is used to mobilise personal loyalty for candidates who share family connections (Sumampouw, 2016: 325). Further, in North Sulawesi, Christian candidates mostly targeted the Gereja Masehi Injili di Minahasa (GMIM, Christian Evangelical Church in Minahasa), the largest Protestant denomination in the province, and built personal associations with religious networks.

Personal networks can also refer to a group of voters having been previously targeted for patronage or constituency services. Viva Yoga Mauladi, a successful candidate from PAN, for instance, targeted what he called base areas where he had distributed patronage in the past (see also Aspinall et al., 2017). As a part of the leadership of a parliamentary commission for agriculture, plantations, forestry and maritime affairs, and fisheries and food affairs, he mostly funnelled his pork-barrel projects to villages or community groups in his electoral district where he had personal or network connections. Such practices weren't limited only to incumbent candidates who could access regular slush funds allocated to their constituents but were also practiced by non-incumbent yet well-resourced candidates who were widely known for their generosity in particular villages. Accordingly, as suggested by Aspinall and his colleagues (2017: 13), most candidates viewed loyal supporters in terms of networks rather than partisan and geographic terms. Viva Yoga, for example, who regularly distributed small-scale infrastructure to local farmer associations, plantation workers, or fishermen groups that were closely related to his portfolio, 
claimed that the members of the groups were his core constituencies (Interview, 22 April 2014).

Overall, the relationships between politicians, brokers, and voters have increasingly been less ideological and more about personal connections and trust. This helps explain why party switching or political turncoatism is pervasive in Indonesia, especially at the constituency level. Some district candidates in a number of regions in South Sumatra move to other parties before an election, but still get elected (Hilmin, interview, 20 November 2014). ${ }^{12}$ It is often the case that when they switch to a new party, they bring their brokerage networks with them. Most brokers simply follow their bosses because they are strongly motivated by personal ties with, and zeal regarding, the candidate rather than party links. If such a shift occurs, the brokers ask their voters to follow as well (Hilmin, interview, 20 November 2014). This couldn't occur were those brokers and their followers strongly tied to their parties. As previously discussed, the nature of vote buying in Indonesia is non-party based, so that brokers' commitment to the candidate and brokers' relationships with voters isn't a matter of ideological conviction about the candidate's party. Rather, it involves a clientelist relationship and personalised networks between candidates and brokers, and between brokers and voters.

\subsection{Maintaining 'Loyalty'}

The discussion thus far has argued that personal networks matter most in explaining targeting strategies. This doesn't mean that candidates ignore areas which have traditionally been viewed as their party bases. As noted above, the personalised nature of voting under the open-list system encourages candidates to personalise party strongholds when pursuing personal votes against co-partisans. But in order to win, they also try to expand their electoral support by targeting areas where they potentially have personal bases mediated by their brokers. In this section, we will explore the next stage, which is when candidates start building intimate social relations with their so-called loyal supporters, trying to lock in their relationship through the provision benefits.

Hence, in order to build and maintain voter loyalty, patronage plays a crucial role as political glue that links voters to candidates and secures their

\footnotetext{
${ }^{12}$ For more discussion about party switching in the case of Indonesia, see Nathan Allen (2012).
} 
votes. In fact, given the significance of patronage in binding voter loyalty, it is sometimes difficult to disentangle patronage from other dimensions of personal networks when explaining electoral outcomes (Warburton, 2016: $351)$. The surveyed candidates and brokers believed that $51 \%$ of their supposedly loyal voters had received 'a lot' or 'quite a lot' of assistance, including money or gifts or construction of roads, houses of worship, insurance, and the like, from the candidate. Meanwhile, only $21 \%$ believed their 'loyalists' hadn't received any inducements. This distribution of material benefits not only occurred during campaigns, most incumbent candidates poured rewards into their voter bases long before the election. ${ }^{13}$ Most candidates I encountered used a variety of terms for this practice, such as 'menyantuni' or 'melayani' (serve or provide services). ${ }^{14} \mathrm{~A}$ commonly shared view among candidates is that they distributed largesse to their constituents because these were the masses of whom they were sure rather than being indifferent groups whose voting behaviour couldn't be determined (see Chap. 4).

By targeting voters whom they suspected to be leaning to them, candidates could minimise potential wastage of their resources. Although targeting such voters wouldn't guarantee that such offers would always be reciprocated, at least candidates would feel more confident that their investments would be translated into more votes than if they distributed to those outside their personal networks of relationships. For instance, one campaign manager, affiliated with a Jakarta-based political consultancy firm, gave me an image of a truck filled with Muslim prayer clothing transported to a group of voters in one district in East Java, because they had committed to support a candidate he was working for (Interview, 2 May 2014). In sum, candidates and brokers preferentially target those who they think will be loyal and reward them with benefits.

But how sure were the candidates and brokers of the loyalty of these allegedly loyal voters? Figure 5.3 suggests that they actually believed the so-called loyal voters also operated according to a 'transactional' logic and were concerned about concrete benefits and immediate rewards. The modal answer to the question about the percentage of 'loyal' voters who

\footnotetext{
${ }^{13}$ Such ongoing relationships that involve reiterated exchanges largely happen among serious candidates-especially incumbents who had been cultivating their constituents long before the election. Many candidates - especially first-timers, however, have no opportunity to build ongoing relationships with voters partly because of their limited access to state patronage.

${ }^{14}$ Also, see Eve Warburton on the case in Southeast Sulawesi (2016: 358-359).
} 


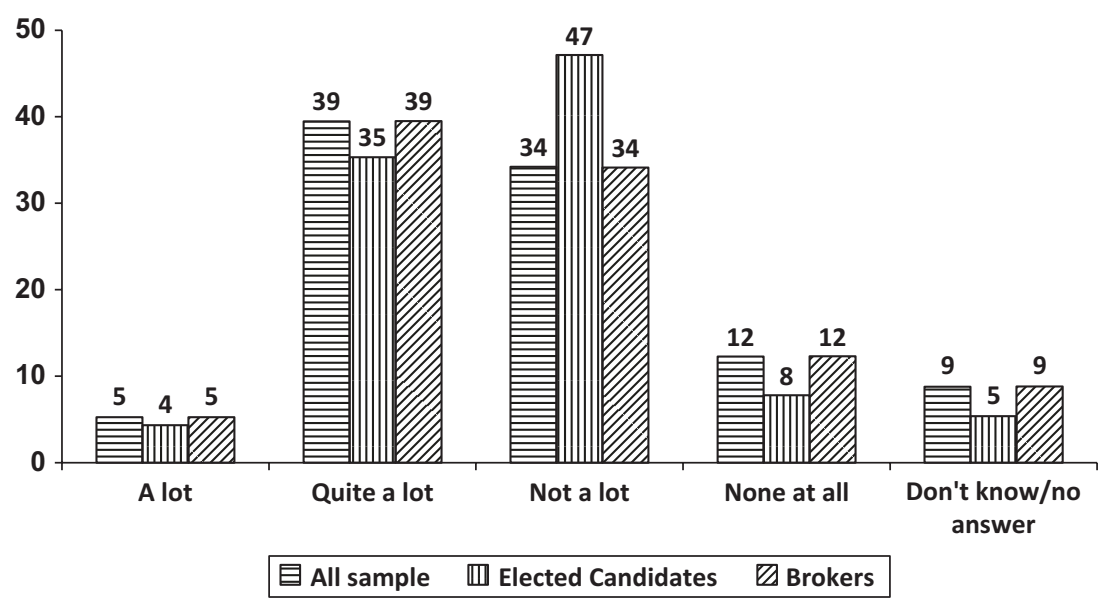

Fig. 5.3 Loyalists who would change their vote if they stopped receiving assistance (\%). Source: My survey of low-level politicians and brokers, 30 September-25 October 2014

would change their vote if they stopped receiving campaign largesse was 'quite a lot,' while about 39\% of the sample saying 'a lot' or 'not a lot.' It is especially striking that - in the respondents' view-only $12 \%$ of respondents believed that all of their 'loyal' voters would remain loyal and would be willing to turn out to vote for them, even if they didn't receive any benefit.

Again, contextual factors really matter in explaining this finding. In particular, Indonesia's highly competitive electoral settings drive candidates to ensure that voters they cultivate will not betray them and switch to cashed-up rivals. The majority of political actors surveyed thought that a significant fraction of their so-called loyal supporters would change their loyalties if not given benefits. As I will discuss in Chap. 7, the high degree of uncertainty induced by zero-sum competition inside party lists encourages candidates to be more responsive to voter demands (Hobolt and Klemmensen, 2008). My finding confirms ethnographic work by Aspinall and his colleagues (2017) who found deep anxiety among politicians regarding their chances of winning and widespread doubt about the allegiance of perceived loyalists who weren't given payments. This is particularly the case when multiple candidates engage in vote buying, and they need to make cash payments-borrowing the words of a Golkar's candi- 
date-'to secure' (mengamankan) their voter base (Interview, 21 April 2014).

This finding might raise doubts about causation. Do candidate consider these people to be loyal voters merely because they have received benefits from them? Or, does their loyalty come first, but need to be 'locked in' by gifts? Although the answer may not be quite clear-cut, I would argue that, at first, candidates map out areas or groups of voters whom they think of as sympathetic, or of having the potential to support them, on the basis of personal relationships, social networks, or past personal patronage. My field observations suggest that candidates then don't take the loyalty of such perceived supporters for granted, with the exception of those who have relational networks or a high degree of personal closeness to the candidates. Instead they use material benefits to lock in their 'loyalty.' The result is that it seems that a lot of what candidates and brokers mean by their 'loyal' voters is simply people or community groups they have provided with benefits. However, as suggested by Aristo Munandar, a Golkar candidate running for a provincial seat legislature in West Sumatra, these benefits don't always come from candidates' own purse, but they can be accessed from state resources. Aristo was proud to claim that, when he was the head of Agam district, he frequently made visits to his constituents, providing them benefits from state funds, often in the form of projects that allowed him to generate loyalty among recipients (Interview, 23 September 2014). Incumbent candidates often rely on public resources and direct them to their base areas as a means of building and maintaining voter loyalty. Then, it is almost as if there is an underlying cultural assumption: "I have helped you, so I can expect your help in return."

The next interesting question is this: if the loyalty of the core supporters depends so much on benefits being offered, what sort of language accompanies such transactions? In most cases, candidates draw upon the language of gift giving, labelling their gifts in religious terminology such as alms (sedekah), or other forms of charitable donations in Islam when attempting to engage the support of their constituents. At the point of exchange with all groups of the electorate, whether loyal or undecided voters, as observed closely by Aspinall and his collaborators (2017: 5) in Java, "candidates and brokers downplayed the significance of their cash gifts and emphasised their emotional bonds with recipients, in line with what we might expect from the anthropological literature."

However, I found a slight difference during my observations. When dealing especially with so-called uncommitted voters, whom political 


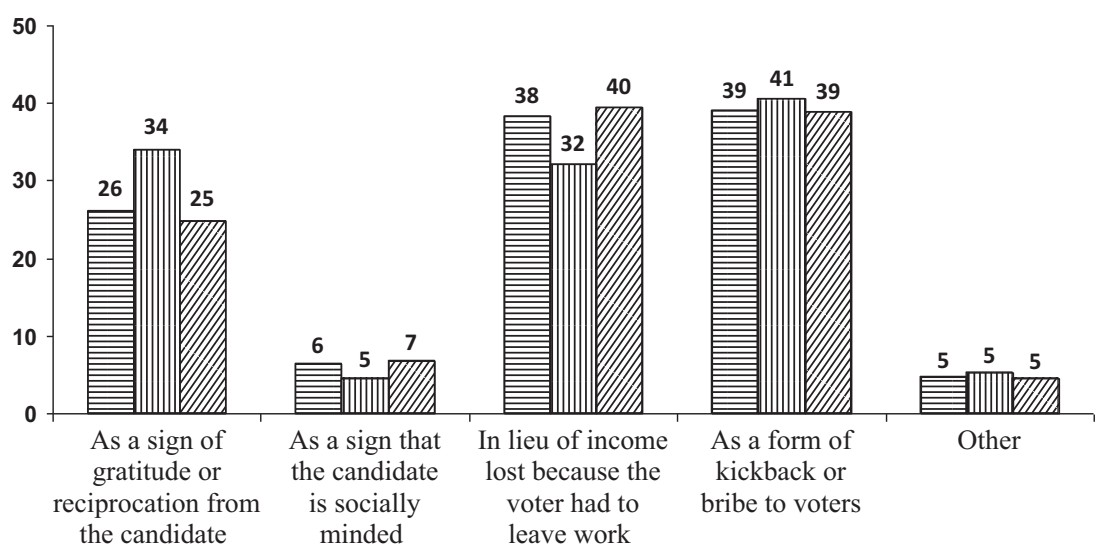

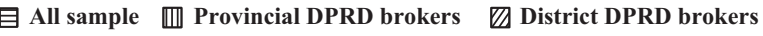

Fig. 5.4 Payments as a binding transaction or gift? Source: My survey of brokers, 30 September-25 October 2014

machines usually called the 'floating masses' (massa mengambang), candidates frequently used economic terms such as 'electoral investment,' 'electoral market price,' and so on. Needless to say, these conversations about the transactional character of floating masses take place behind the backs of the voters. To be fair, the negative characterisation isn't exclusively directed at such voters, suggesting that supposedly loyal voters are occasionally associated with a transnational logic too, if not secured with a gift. But candidates and brokers appeared to be more lenient or benevolent if the payments were directed to the so-called loyalists rather than uncommitted voters.

This qualitative finding corresponds with the results from my broker survey. As shown in Fig. 5.4, when asked what motivated candidates to engage in vote buying, ${ }^{15}$ while responses were quite scattered, a significant proportion of the sample said 'as a form of kickback to voters' (39\%) and 'as compensation in lieu of wages lost because the voter had to leave work to come to the polls' (38\%). About $26 \%$ of the respondents viewed the offer as 'a sign of gratitude or reciprocation from candidates.' Interestingly, when I ran cross-tabulation tables, brokers who targeted undecided voters were more likely to consider the gifts as 'a form of kickback to voters.' In

${ }^{15}$ The question reads: "According to you, what is the motivation of the candidate who distributed the envelope/money/goods to the voters prior to the election?" [answer can be more than one]. 
contrast, those brokers who were targeting loyal supporters were more likely to view the payment 'in lieu of income lost because voters had to leave work,' or 'as a sign of gratitude from the candidate,' or 'as a sign that the candidate is socially minded.' There are indications that intermediaries can tolerate such compensation for 'loyal' voters partly because they view such voters as being more reciprocal than undecided voters. Regardless of the fact that some perceived loyalists can end up voting for rivals, they were seen to be more reliable in delivering support to the distributing candidate.

Having presented the results of my study, one might question the meaning of the very concept of 'loyal voters' in the Indonesian context. If these voters are truly loyal, as claimed by candidates and brokers, why do they need to be given rewards at all? If they are genuine loyalists, they should turn out of their own accord and vote for their own party or candidate without being enticed with a benefit (Stokes et al., 2013: 111). This widely held assumption, however, isn't supported by the facts in the Indonesian case. As alluded to earlier, detailed studies of grassroots electioneering for the 2014 elections by Aspinall and his colleagues (2017:2), for example, capture candidates' "deep anxiety about the reliability of even supposedly loyal voters, suggesting that their votes were vulnerable if not secured with a payment." Hence, the loyalty of the so-called loyal voters cannot be taken for granted since their allegiance to the candidate tends to be affected by short-term electoral incentives. In short, candidates face two related but distinct risks from targeting swing voters. First, that swing voters might take the money but not vote for them. Second, that a core voter who doesn't get funds will defect. The latter seems the bigger risk for candidates, which calls into question whether it is appropriate to call a group of voters that candidates target as a 'core.'

It is worth noting that my finding in Indonesia differs from those in the study of Diaz-Cayeros and his colleagues (2012) in the case of Mexico. They found that political parties favoured their partisan voters as an artefact of endogenous party loyalty. Diaz-Cayeros et al. (2012:23) argue that "if swing voters are constantly targeted with benefits, core voters will no longer tolerate it, and will soon become open to mobilisation by other political parties, behaving much like swing voters in future elections." In their theoretical framework, party loyalty is conditional, or endogenous, rather than fixed. The Indonesian case is different. The driving factor behind candidates' insistence on giving cash to their 'loyal' supporters is suspicion of the allegiance of their perceived loyalists in the context of 
increasing electoral uncertainty induced by intense intraparty competition. In addition, as noted above, voter loyalty in Indonesia isn't framed in terms of partisan convictions, as the literature (including Diaz-Cayeros et al., 2012) conventionally assumes. Given that beneficiaries are in practice largely selected in terms of personal network relationships, we witnessed why the targeting of so much vote buying ends up in the hands of undecided voters who don't always reciprocate with votes.

\subsection{Conclusion}

So, how do politicians in Indonesia determine which voters to target? When it comes to the targeting strategies, the existing literature offers two conflicting schools. As we have seen, one school of thought holds that in terms of distributing cash payments, political machines favour their core supporters over ideologically indifferent voters (e.g. Nichter, 2008; DiazCayeros et al., 2012; Stokes et al., 2013). Another school claims that parties will not squander their limited budgets on core supporters, but instead expend them on swing voters in an attempt to convince them to support the giver (e.g. Lindbeck and Weibull, 1987; Dixit and Londregan, 1996; Stokes, 2005).

At first, my findings seem to show that candidates and intermediaries tend to target constituents who they think of as being truly loyal, strongly evocative of core-voter strategy. Moreover, the logic of various elements of Indonesia's institutional framework, such as optional voting, open-list PR, and ballot secrecy, provides strong incentives for political machines to favour party loyalists because such voters are thought of as being more reciprocal, and as a more predictable source of votes. Yet, theoretically, the model is built on the assumption that voters can be categorised 'loyalist' as long as they are proximate to a party in ideological or partisan terms (Stokes et al., 2013: 45). However, the number of partisan voters is limited in Indonesia, and this small segment of voters is highly contested among co-partisans in the context of open-list PR which incentivises zerosum, intraparty competition.

If candidates and broker really favour only their loyal party supporters, as sometimes seems suggested by how they describe their strategies, how could they expect to win, given the limited number of such voters? In an attempt to address this puzzle, this chapter offers an alternative explanation to the literature by highlighting the importance of personal networks in explaining clientelist strategies in Indonesia. My argument works for a 
context where partisan ties are relatively weak, where the electoral system is candidate-centric, where the organisation of vote buying isn't partybased, and where personalised loyalties matter far more. Given the party's captives are both limited and contested among internal rivals, candidates skilfully use their personal networks as the major tool of voter mobilisation. These personal networks have multiple dimensions ranging from kinship, ethnic, and religious ties, to patronage to brokerage networks. In short, the empirical evidence paints a picture largely consistent with the personal loyalist (i.e. people who were selected through personal networks) strategy I highlight.

The reliance on such networks, however, makes the personal loyalist strategy vulnerable to the problems of targeting and principal-agent breakdown that arise in the relations between candidates, brokers, and voters. In particular, this chapter has identified a pattern in the allocation of vote buying where, despite politicians' and brokers' strongly expressed preference for targeting loyalists, they end up distributing to voters who are in fact not loyal to the candidates. I have discussed three major difficulties associated with the personal loyalist strategy: first, candidates and brokers misidentify the number of loyal voters because they tend to mix up partisan and personal loyalties. Second, the loyalty concept in Indonesia is ambiguous and has multiple dimensions relying on a more personalised rather than strictly party-based relationships. Unsurprisingly, when it comes to determining who gets targeted for vote buying, candidates depend on personal networks rather than judging their targets in terms of partisan and ideological leanings. Third, agency loss also explains why the targeting of vote buying ends up with voters who don't reciprocate. Candidates obviously know that brokers have an interest in exaggerating their influence. They are also aware that voters whom brokers classify as loyal are often typically contested by brokers working for rival candidates and often receive multiple payments. Even so, precisely because political actors aren't really confident about the 'loyalty' of their so-called loyal voters, they typically fear many such voters will not vote for them unless they receive gifts.

In conclusion, the targeting strategy in Indonesia must be seen as a distinctive type that functions like neither the core-voter nor the swingvoter model. Much of the literature on core- and swing-voter models is framed by a context different from that in Indonesia. The existing literature relies on the underlying assumption that party machines are both engaged with voters and capable of mobilising them. This sort of analysis 
doesn't fit the Indonesian context, where elections have been largely driven by candidate-centred politics in which a lot of the connections with voters aren't mediated by parties, but instead by informal brokerage networks. The differences in context make the dynamics of vote buying, at least the targeting, very distinctive.

\section{BiBLIOGRAPHY}

\section{Books, Journal Articles, and Unpublished Papers}

Allen, N.W. (2012) Diversity, Patronage and Parties: Parties and Party System Change in Indonesia. PhD dissertation, The University of British Columbia, Vancouver, BC Canada.

Aspinall, E., Mietzner, M., and Tomsa, D. (2015) The Yudhoyono Presidency: Indonesia's Decade of Stability and Stagnation. Singapore: ISEAS.

Aspinall, E., Rohman, N., Hamdi, A.Z., Rubaidi, and Triantini, Z. (2017) Vote Buying in Indonesia: Candidate Strategies, Market Logic and Effectiveness. Journal of East Asian Studies 17: 1-27.

Auyero, J. (2001) Poor People's Politics: Peronist Networks and the Legacy of Evita. Durham, NC: Duke University Press.

Berenschot, W. (2015) Political Parties and Clientelism in Southeast Asia. Bijdragen tot de Taal-, Land- en Volkenkunde 171: 557-562.

Cox, G.W. and McCubbins, M.D. (1986) Electoral Politics as a Redistributive Game. The Journal of Politics 48(2): 370-389.

Diaz-Cayeros, A., Estévez, F., and Magaloni, B. (2012) Strategies of Vote Buying: Democracy, Clientelism and Poverty Relief in Mexico. Viewed at https://web. stanford.edu/ magaloni/dox/2012strategiesvotebuying.pdf. Accessed 17 October 2015.

- (2016) The Political Logic of Poverty Relief: Electoral Strategies and Social Policy in Mexico. Cambridge: Cambridge University Press.

Dixit, A. and Londregan, J. (1996) The Determinants of Success of Special Interests in Redistributive Politics. Journal of Politics 58(4): 1132-1155.

Eder, J.F. (1991) Political Transition in a Palawan Farming Community. In: B. Kerkvliet and R.B. Mojares (eds) From Marcos to Aquino: Local Perspectives on Political Transition in the Philippines. Honolulu: University of Hawaii Press.

Finan, F. and Schechter, L. (2012) Vote Buying and Reciprocity. Econometrica 80(2): 863-881.

Gans-Morse, J., Mazzuca, S., and Nichter, S. (2014) Varieties of Clientelism: Machine Politics during Elections. American Journal of Political Science 58(2): 415-432. 
Hicken, A., Leider, S., Ravanilla, N., and Yang, D. (2017) Temptation in VoteSelling: Evidence from a Field Experiment in the Philippines. Unpublished manuscript. http://www-personal.umich.edu/ leider/Papers/TemptationVote Selling.pdf. Accessed 16 May 2017.

Hobolt, S.B. and Klemmensen, R. (2008) Government Responsiveness and Political Competition in Comparative Perspective. Comparative Political Studies 4l(3): 309-337.

Holland, A.C. and Palmer-Rubin, B. (2015) Beyond the Machine: Clientelist Brokers and Interest Organizations in Latin America. Comparative Political Studies 48(9): 1186-1223.

Kramon, E. (2013) Vote Buying and Accountability in Democratic Africa. PhD dissertation, UCLA, CA, USA.

Levitsky, S. (2003) Transforming Labor-Based Parties in Latin America: Argentine Peronism in Comparative Perspective. Cambridge: Cambridge University Press.

Lindbeck, A. and Weibull, J.W. (1987) Balanced-budget Redistribution as the Outcome of Political Competition. Public Choice 52: 273-297.

Mainwaring, S. (1991) Politicians, Parties, and Electoral Systems: Brazil in Comparative Perspective. Comparative Politics 24(1): 21-43.

Nichter, S.C. (2008) Vote Buying or Turnout Buying? Machine Politics and the Secret Ballot. American Political Science Review 102(1):19-31.

- (2010) Politics and Poverty: Electoral Clientelism in Latin America. PhD thesis, University of California at Berkeley, USA.

Schaffer, F.C. (2005) Clean Elections and the Great Unwashed: Educating Voters in the Philippines. Occasional Paper 21, School of Social Science, IAS.

Schaffer, F.C. and Schedler, A. (2007) What is Vote Buying? In: F.C. Schaffer (ed) Elections for Sale: The Causes and Consequences of Vote Buying. Boulder: Lynne Reinner.

Shugart, M.S. (2001) Extreme' Electoral Systems and the Appeal of the Mixedmember Alternative. In: M.S. Shugart and M.P. Wattenberg (eds) Mixedmember Electoral Systems. The Best of Both Worlds? Oxford: Oxford University Press.

Stokes, S.C. (2005) Perverse Accountability: A Formal Model of Machine Politics with Evidence from Argentina. American Political Science Review 99(3): $315-325$.

- (2007) Is Vote Buying Undemocratic? In: F.C. Schaffer (ed) Elections for Sale: The Causes and Consequences of Vote Buying. Colorado: Lynne Rienner Publisher, Inc.

Stokes, S.C., Dunning, T., Nazareno, M., and Brusco, V. (2013) Brokers, Voters and Clientelism: The Puzzle of Distributive Politics. New York: Cambridge University Press. 
Sumampouw, N.S.A. (2016) North Sulawesi: Clan, Church and State. In: E. Aspinall and M. Sukmajati (eds) Electoral Dynamics in Indonesia: Money Politics, Patronage and Clientelism at the Grassroots. Singapore: NUS Press.

Tomsa, D. and Ufen, A. (eds) (2012) Party Politics in Southeast Asia. Clientelism and Electoral Competition in Indonesia, Thailand and the Philippines. Milton Park: Routledge.

Thomassen, J. and Rosema, M. (2009) Party Identification Revisited. In: J. Bartle and P. Bellucci (eds) Political Parties and Partisanship: Social Identity and Individual Attitudes. London: Routledge.

Warburton, E. (2016) Southeast Sulawesi: Money Politics in Indonesia's Nickel Belt. In: E. Aspinall and M. Sukmajati (eds) Electoral Dynamics in Indonesia: Money Politics, Patronage and Clientelism at the Grassroots. Singapore: NUS Press.

Open Access This chapter is licensed under the terms of the Creative Commons Attribution 4.0 International License (http://creativecommons.org/licenses/ by $/ 4.0 /$ ), which permits use, sharing, adaptation, distribution and reproduction in any medium or format, as long as you give appropriate credit to the original author(s) and the source, provide a link to the Creative Commons licence and indicate if changes were made.

The images or other third party material in this chapter are included in the chapter's Creative Commons licence, unless indicated otherwise in a credit line to the material. If material is not included in the chapter's Creative Commons licence and your intended use is not permitted by statutory regulation or exceeds the permitted use, you will need to obtain permission directly from the copyright holder.

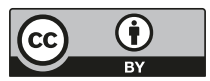

